\title{
Tunnel channel formation during the November 1996 jökulhlaup, Skeiðarárjökull, Iceland
}

\author{
Andrew J. RUSSELL, ${ }^{1}$ Andrew R. GREGORY, ${ }^{1}$ Andrew R.G. LARGE, ${ }^{1}$ P. Jay FLEISHER, ${ }^{2}$ \\ Timothy D. HARRIS ${ }^{3}$ \\ ${ }^{1}$ School of Geography, Politics and Sociology, Daysh Building, University of Newcastle upon Tyne NE1 7RU, UK \\ E-mail: Andy.Russell@ncl.ac.uk \\ ${ }^{2}$ Department of Earth Sciences, SUNY College at Oneonta, NY 13820-4015, USA \\ ${ }^{3}$ Department of Geography, Staffordshire University, College Road, Stoke-on-Trent, Staffordshire ST4 2DE, UK
}

\begin{abstract}
Despite the ubiquity of tunnel channels and valleys within formerly glaciated areas, their origin remains enigmatic. Few modern analogues exist for event-related subglacial erosion. This paper presents evidence of subglacial meltwater erosion and tunnel channel formation during the November 1996 jökulhlaup, Skeiðarárjökull, Iceland. The jökulhlaup reached a peak discharge of 45000 to $50000 \mathrm{~m}^{3} \mathrm{~s}^{-1}$, with flood outbursts emanating from multiple outlets across the entire $23 \mathrm{~km}$ wide glacier snout. Subsequent retreat of the southeast margin of Skeiðarárjökull has revealed a tunnel channel excavated into the surrounding moraine sediment and ascending $11.5 \mathrm{~m}$ over a distance of $160 \mathrm{~m}$ from a larger trough to join the apex of an ice-contact fan formed in November 1996. The tunnel channel formed via hydro-mechanical erosion of $14000 \mathrm{~m}^{3}$ to $24000 \mathrm{~m}^{3}$ of unconsolidated glacier substrate, evidenced by copious rip-up clasts within the ice-contact fan. Flow reconstruction provides peak discharge estimates of $680 \pm 140 \mathrm{~m}^{3} \mathrm{~s}^{-1}$. The tunnel channel orientation, oblique to local ice flow direction and within a col, suggests that local jökulhlaup routing was controlled by (a) subglacial topography and (b) the presence of a nearby proglacial lake. We describe the first modern example of tunnel channel formation and illustrate the importance of pressurized subglacial jökulhlaup flow for tunnel channel formation.
\end{abstract}

\section{INTRODUCTION}

Tunnel valleys and tunnel channels are common within the Quaternary landform and sedimentary record of North American and European ice sheet margins (e.g. Wright, 1973; Ehlers and Linke, 1989; Brennand and Shaw, 1994; Clayton and others, 1999; Jørgensen and Sandersen, 2006). Tunnel valley networks and sedimentary fills have been identified within Late Ordovician and Late Paleozoic successions (Ghienne and Deynoux, 1998; Eyles and de Broekert, 2001). Tunnel valleys are elongate depressions cut into unconsolidated sediment or bedrock, with typical lengths of $1-100 \mathrm{~km}$, widths of up to $4 \mathrm{~km}$ and depths of up to $400 \mathrm{~m}$. Tunnel valleys can either be infilled with sediment or remain unfilled, forming an unfilled channel (O'Cofaigh, 1996; Russell and others, 2003; Jørgensen and Sandersen, 2006; Hooke and Jennings, 2006). Although tunnel valleys are known to have a subglacial genesis, numerous mechanisms have been proposed to explain their origin. Boulton and Hindmarsh (1987) proposed that deforming subglacial sediment would flow towards low-pressure zones around conduits, allowing progressive evacuation of subglacial sediment and tunnel valley generation. Piotrowski (1997) argued that, for glacially-charged aquifers, groundwater flux alone was incapable of instantaneously discharging large meltwater volumes and suggested instead that excess meltwater accumulation at the glacier bed resulted in periodic jökulhlaups, which excavate subglacial sediments to produce tunnel valleys. While large-scale sedimentary structures within some tunnel valley sediment fills indicate time-transgressive formation (Praeg, 2003), fluvial excavation remains one of the most frequently proposed hypotheses to explain the origin and characteristics of tunnel valley systems (e.g. Wingfield, 1989, 1990; Ghienne and Deynoux, 1998; Huuse and Lykke-Andersen, 2000; Jørgensen and Sandersen, 2006; Hooke and Jennings, 2006). Tunnel valleys may be modified by numerous processes acting over considerable time spans. Björnsson (1996) for example has highlighted the role of meltwater in excavating a $300 \mathrm{~m}$ deep subglacial trough at Breiðamerkurjökull, Iceland, since the Little Ice Age glacier advance. Tunnel channels, by contrast, are thought to be created by bank-full flow conditions (Brennand and Shaw, 1994; Clayton and others, 1999; Beaney, 2002; Cutler and others, 2002; Sjogren and others, 2002; Smith, 2004; Fisher and others, 2005). Tunnel channel systems are commonly tens of kilometres in length orientated towards former ice margins directly into proglacial outwash deposits (Clayton and others, 1999; Cutler and others, 2002; Kozlowski and others, 2005). Many tunnel channels ascend adverse bed topography suggesting that subglacial flow within the channels was pressurized and flowing down a hydraulic gradient controlled by ice-surface elevation (Clayton and others, 1999; Johnson, 1999; Cutler and others, 2002; Hooke and Jennings, 2006; Jørgensen and Sandersen, 2006). In the literature there is considerable debate as to the magnitude and frequency of tunnel channel forming flows. Hypotheses include a sudden or catastrophic origin during glacier outburst floods, or more steady-state conditions associated with progressive headward sapping by deformable bed sediment or seasonal meltwater flows (e.g. Mooers, 1989; Wright, 1973; Hooke and Jennings, 2006). Recent research along the Laurentide Ice Sheet margin suggests periodic glacier outbursts associated with meltwater storage and release behind zones of frozen glacier bed (Clayton and others, 1999; Cutler and others, 2002; Hooke and Jennings, 2006). 

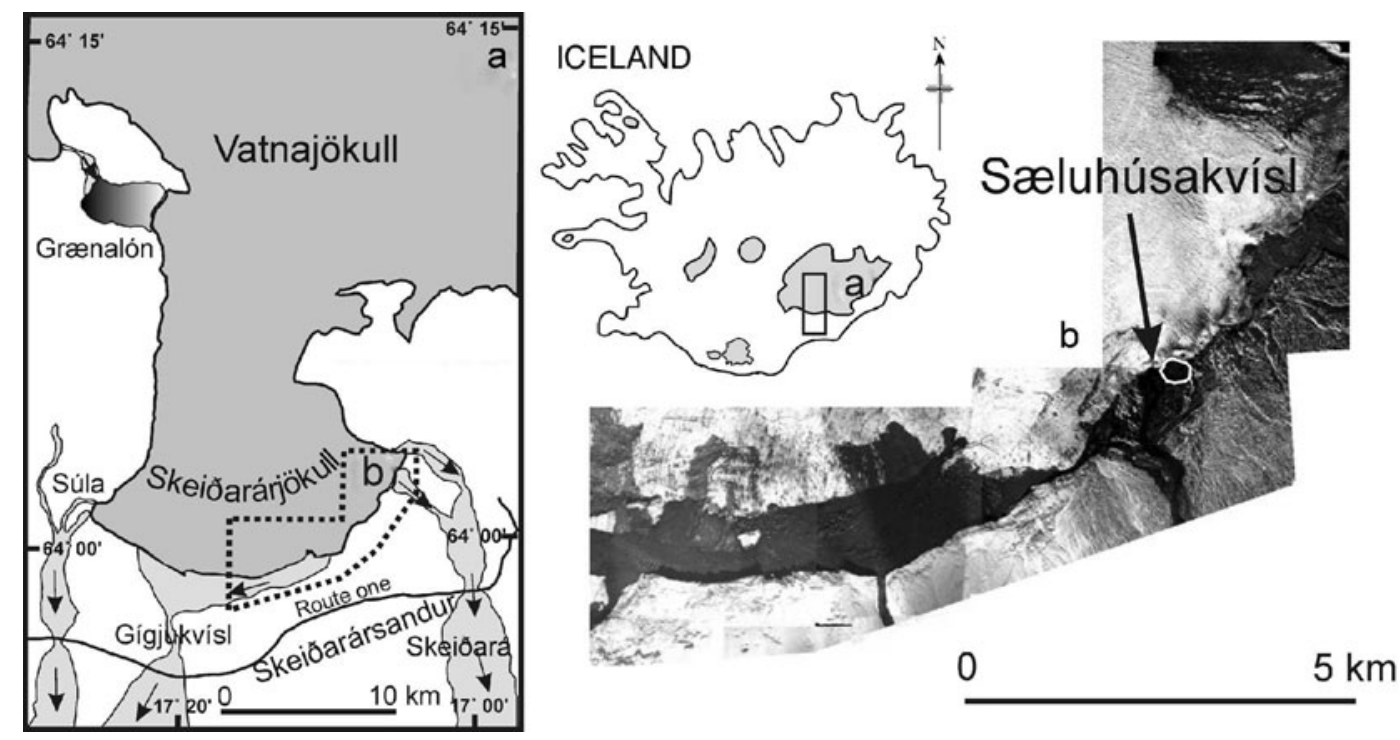

Fig. 1. (a) Location of Skeiðarárjökull and Skeiðarársandur within Iceland and in relation to Vatnajökull ice cap. (b) Aerial photograph of waning stage jökulhlaup flows within the Gígjukvísl channel system at 12:00 on 6 November 1996. The location of Sæluhúsakvísl outlet and Sæluhúsavatn lake basin are indicated.

Despite the relative abundance of literature concerning Quaternary tunnel channel genesis, there are no examples of tunnel-channel formation within contemporary glacial systems. This gap has commonly been attributed to a lack of appropriate modern conditions for tunnel channel genesis or the inaccessibility of the subglacial environment (Jørgensen and Sandersen, 2006). This paper addresses this lacuna and presents the first modern example of tunnel
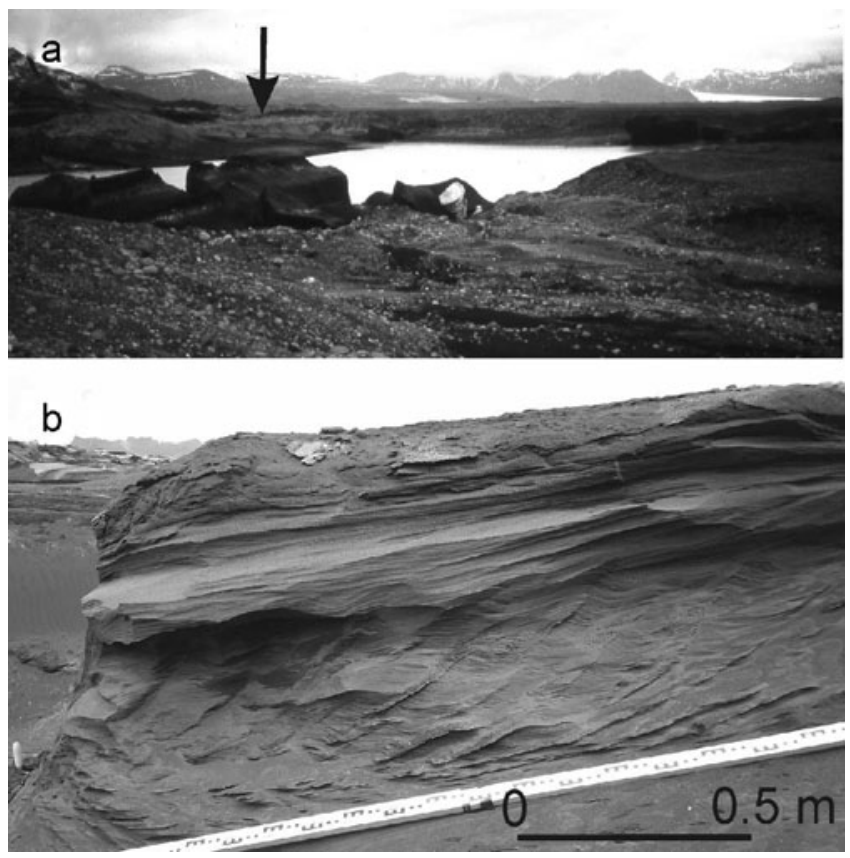

Fig. 2. (a) View of the upper Sæluhúsavatn basin in April 1997. Perched delta on the far side of the lake basin and stranded ice blocks indicate higher lake levels prevailed during the jökulhlaup. (b) Climbing ripple sequence exposed within the upper Sæluhúsavatn, approximately $50 \mathrm{~m}$ from the position of the 1996 ice margin. Climbing ripples indicate very high sedimentation rates and a flow direction directly away from the glacier margin. channel formation during a glacier outburst flood or 'jökulhlaup' under well-constrained event magnitude, duration and impact.

\section{Aims}

The aims of this paper are: (1) to present new evidence of subglacial meltwater erosion and tunnel channel formation during the November 1996 jökulhlaup, Skeiðarárjökull, Iceland; and (2) from this evidence, determine the controls on tunnel channel routing and morphology.

\section{NOVEMBER 1996 JÖKULHLAUP}

A volcanic eruption beneath the Vatnajökull ice cap began on 30 September 1996 (Guðmundsson and others, 1997). Over the following month, $3.8 \mathrm{~km}^{3}$ of meltwater travelled subglacially into the Grímsvötn subglacial lake until it reached a critical level for drainage (Björnsson, 2002). The resulting jökulhlaup began in Skeiðará, the most easterly river draining Skeiðarárjökull (Fig. 1), on the morning of 5 November, and reached a peak discharge of $45-53 \times$ $10^{3} \mathrm{~m}^{3} \mathrm{~s}^{-1}$ within 14 hours (Björnsson, 2002; Snorrason and others, 1997, 2002). After its release from Grímsvötn, the jökulhlaup propagated as a high-pressure subglacial flood wave taking 10.5 hours to reach the glacier snout (Roberts and others, 2000; Jóhannesson, 2002; Roberts, 2005; Flowers and others, 2004). Floodwater burst from numerous outlets across the entire $23 \mathrm{~km}$ wide ice margin (Russell and Knudsen, 1999; Roberts and others, 2000) (Fig. 1). As the jökulhlaup progressed, discharge from the glacier became progressively focussed on major conduit outlets (Roberts and others, 2000; Roberts, 2005; Flowers and others, 2004). Notably, to exit the glacier, floodwaters had to ascend about $300 \mathrm{~m}$ to the sandur surface (Björnsson, 1998; Roberts and others, 2002).

Evidence for large-scale erosion of glacier substrate during the November 1996 jökulhlaup takes the form of copious numbers of intraclasts or rip-ups found in en- and proglacial jökulhlaup deposits (Russell and Knudsen, 1999; Roberts and others, 2001; Waller and others, 2001; Russell 

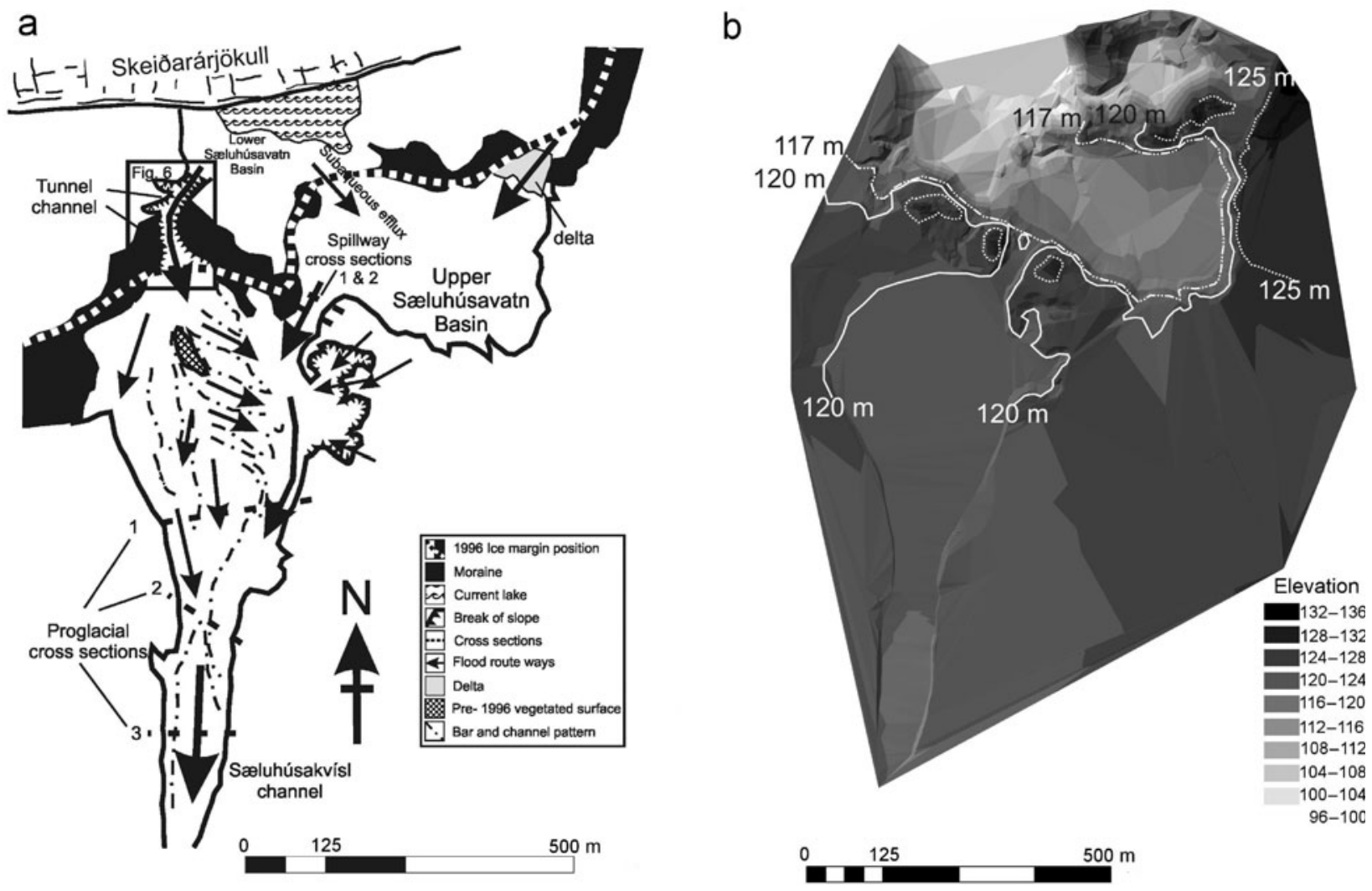

Fig. 3. (a) Map of the field area, indicating the location of channel and spillway cross-sections used to reconstruct 1996 jökulhlaup discharge for this system. (b) Elevation model for the field area derived from over 2000 DGPS survey points.

and others, 2006). The event-based erosion is also seen in published sediment budget calculations for the proglacial area (Roberts, 2005; Russell and others, 2006). As Grímsvötn subglacial lake acted as a sediment trap for coarsegrained eruption products, the entire solid sediment load of the jökulhlaup downstream of Grímsvötn was solely derived from fluvial erosion of older volcaniclastic, glacial and glaciofluvial sediments (Stefánsdóttir and others, 1999). The estimated total sediment flux during the 1996 jökulhlaup of $1.8 \times 10^{8} \mathrm{~m}^{3}$ suggests tunnel channel excavation may have occurred (Roberts, 2005). Although it is known that subglacial erosion took place during the November 1996 jökulhlaup, no knowledge exists of the spatial distribution and geomorphological expression of erosion. It is notable, however, that between 1996 and 2006, the snout of Skeiðarárjökull thinned by about $100 \mathrm{~m}$ and retreated by up to $1 \mathrm{~km}$. In particular, ice margin retreat near the Sæluhúsavatn proglacial lake has progressively revealed a subglacial feeder channel to Sæluhúsakvísl, one of the November 1996 jökulhlaup outlets (Figs 1 and 2).

\section{METHODS}

Fieldwork was undertaken in the Sæluhúsakvísl area of Skeiðarársandur in April 1997, March 2004, July 2005 and April 2006 (Fig. 1). The site was surveyed using Differential Global Positioning System (DGPS) allowing construction of a terrain model of the field area (2331 points) and the mapping of flood wash limits and flood channel morphology (165 points). Within-channel surface grain sizes and bedforms were noted at regular intervals to allow characterization of grain and form roughness. Channel cross-sectional areas, water surface slopes and roughness were used to reconstruct peak jökulhlaup discharge within the Sæluhúsakvísl tunnel channel and Sæluhúsavatn proglacial lake outflow channels.

\section{SALUHÚSAVATN PROGLACIAL LAKE BASIN}

The Sæluhúsavatn upper basin was full of water prior to and immediately following the November 1996 jökulhlaup (Figs 2a, 3 and 4). Stranded ice blocks and silt deposits observed in April 1997 indicated that lake levels rose by several metres during the jökulhlaup (Figs $2 \mathrm{a}$ and $3 \mathrm{~b}$ ). A coarse-grained boulder delta deposited on the eastern margin of the lake indicates subaerial jökulhlaup influx to the basin (Figs 2a and 3). Sedimentary infill of the upper Sæluhúsavatn basin includes a 1-2 m thick unit of sandy climbing ripples capped by laminated silt (Fig. 2b). Palaeocurrent direction is directly away from the former glacier margin (Figs $2 \mathrm{~b}$ and $4 \mathrm{a}$ ). Other sedimentary facies include massive sand units containing out-sized cobbles and intraclasts composed of laminated silts. Located within $50 \mathrm{~m}$ of the 1996 glacier margin, all of these facies are the product of high sedimentation rates and rapid reworking within a lacustrine environment (Allen, 1982a, b; Ashley and others, 1982). This finding is consistent with subaqueous jökulhlaup efflux into the upper Sæluhúsavatn lake basin (Fig. 4). Jökulhlaup water exited the Sæluhúsavatn basin initially through a number of spillway channels on the western margin of the lake basin, generating a series of cataracts (Figs $3 \mathrm{~b}$ and 4). Progressive spillway erosion during a later stage of the jökulhlaup accounted for most of the lake outflow. 

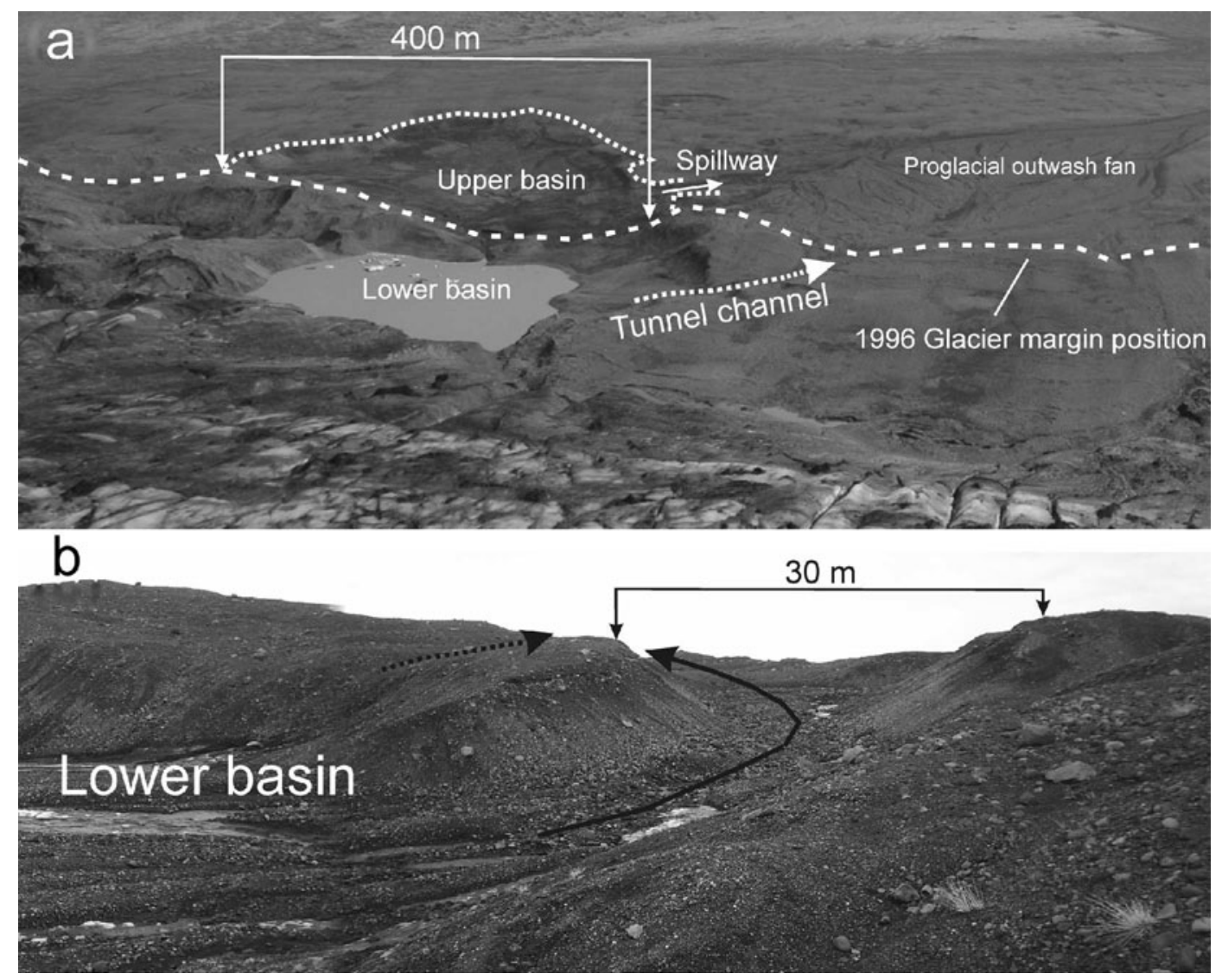

Fig. 4. (a) Oblique aerial photograph taken in August 2005 indicates the location of the tunnel channel in relation to the 1996 glacier margin position, proglacial outwash fan and lower Sæluhúsavatn basin. View is from the glacier (in foreground) towards the proglacial area. (b) View from lower Sæluhúsavatn basin up the tunnel channel towards the former ice margin. A smaller channel is truncated by the main tunnel channel.

\section{REVERSE-GRADIENT CHANNEL AND PROGLACIAL OUTWASH FAN}

A channel ascends from the lower Sæluhúsavatn basin directly to the head of a distinctive proglacial outwash fan deposited by the 1996 jökulhlaup (Figs 4a and b). Postjökulhlaup observations reveal a broad, low channel-shaped depression excavated into the surrounding moraine sediment rather than into the overlying ice (Figs $5 \mathrm{a}-\mathrm{c}$ ). The channel bottom ascends $11.5 \mathrm{~m}$ over a distance of $160 \mathrm{~m}$ and has an average reverse gradient of $0.07(\mathrm{~m} / \mathrm{m}$ ) (Figs $3 b$, $4 a, 4 b$ and 6). The channel bed becomes shallower as it ascends (Fig. 6). Two tributary gullies entering the channel on its western margin represent post-jökulhlaup meltwater reworking during deglaciation of the channel area (Figs 3b, 4 and 6). In order to avoid these post-jökulhlaup channel modification zones, cross-sectional profiles were surveyed between the tributary gullies and the 1996 ice margin (Figs $3 \mathrm{~b}$ and 6). Bank-full channel cross-sectional areas of between $50 \mathrm{~m}^{2}$ and $90 \mathrm{~m}^{2}$ were derived from channel widths of $25-40 \mathrm{~m}$ respectively (Fig. 6). The channel base has a relatively smooth appearance when compared to adjacent moraine deposits and the channel margins are characterized by clear breaks of slope in the surrounding moraine sediment (Fig. 5b). With depths restricted to $0.7-2.2 \mathrm{~m}$, the main channel is characteristically wide and shallow, and truncates another shallow channel ascending from the lower Sæluhúsavatn basin (Figs $4 \mathrm{~b}$ and 6). A figure for the volume of eroded sediment of $14000 \mathrm{~m}^{3}$ was derived by extrapolating surveyed cross-sectional areas $\left(90 \mathrm{~m}^{2}\right)$ along the channel length of $160 \mathrm{~m}$. However, a greater channel cross-sectional area $\left(190 \mathrm{~m}^{2}\right)$ within the first $100 \mathrm{~m}$ of the channel as it ascends from the lower Sæluhúsavatn basin suggests that a total of $24000 \mathrm{~m}^{3}$ of sediment was eroded (Figs $4 \mathrm{~b}$ and 6).

The bar pattern of the proglacial outwash fan indicates rapid flow expansion from the former channel portal, with the upper fan surfaces sloping in a radial fashion away from the channel portal (Figs 3a and 4a). The centre of the fan is incised to a depth of $4 \mathrm{~m}$ to the pre-jökulhlaup surface (Russell and Knudsen, 2002) (Figs 5a and b). Copious numbers of rip-ups or intraclasts composed of glaciofluvial sediment are found on the fan, which also contains sediment of up to boulder size (Figs 5a and b). Relatively few ice block obstacle marks are found on the fan compared with other 1996 jökulhlaup outwash fans (Russell and Knudsen, 1999, 2002; Fay, 2002). The fan has an estimated volume of $70000 \mathrm{~m}^{3}$ based on an average thickness of $2 \mathrm{~m}$ and an area of $35000 \mathrm{~m}^{2}$.

\section{FLOW RECONSTRUCTION}

Peak jökulhlaup discharge was estimated within the Sæluhúsakvísl proglacial channel using four variants of the slope-area technique. Flows were reconstructed at three proglacial channel cross-sections and a further two crosssections within a spillway channel exiting the Sæluhúsavatn proglacial lake basin (Figs 3a and 6). The proglacial channel cross-sections were inundated solely by jökulhlaup flow 

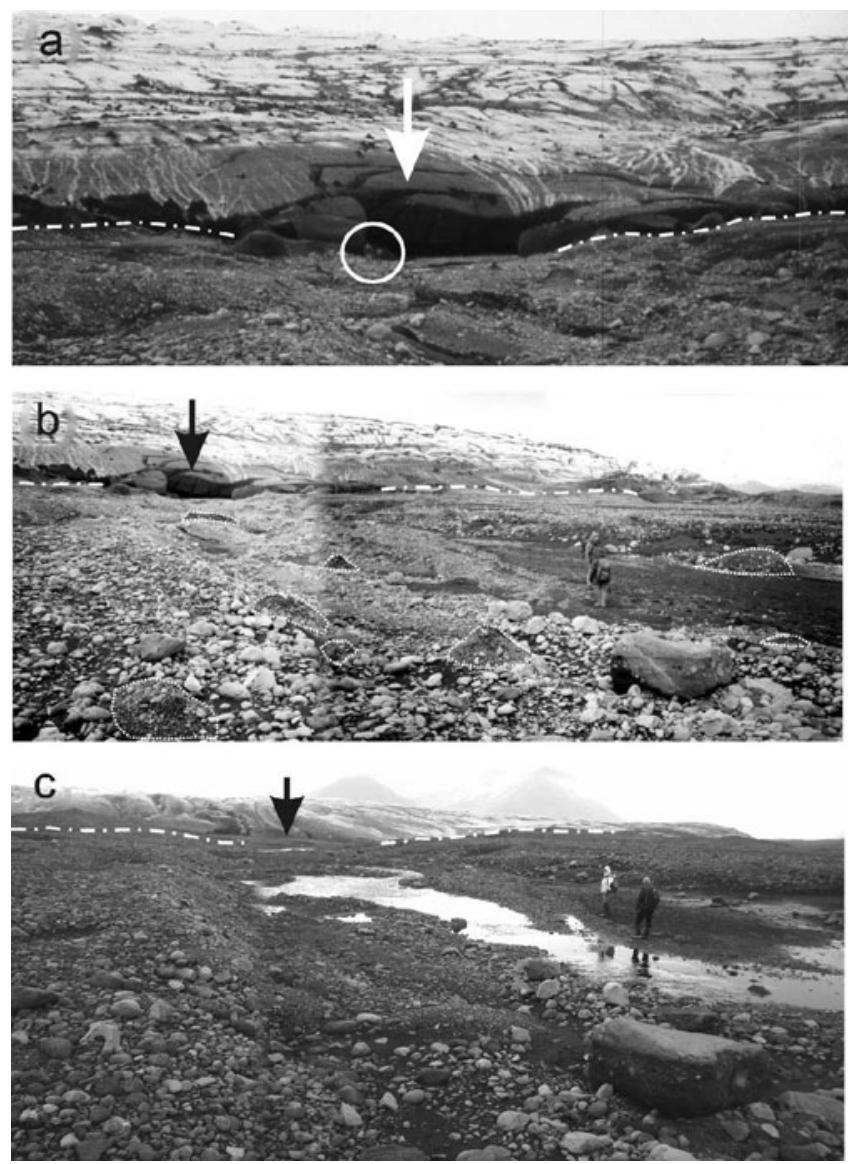

Fig. 5. (a) View of the mouth of the Sæluhúsakvísl outlet in April 1997 illustrating channel incision into moraines on either side (note people for scale). Waning stage erosion dissecting rising stage jökulhlaup deposits, creating a prominent proglacial channel leading towards the viewer. (b) Taken in April 1997 this view shows the central portion of the proglacial outwash fan littered with numerous rip-ups or intraclasts. Waning stage fan incision has exhumed the pre-jökulhlaup vegetated surface near to the people. (c) The same view as in (b) taken in March 2004, illustrating degradation of the intraclasts on an otherwise unaltered surface. Ice margin retreat shows the mouth of the tunnel channel cutting through adjacent moraine ridges.

exiting the Sæluhúsavatn proglacial lake and the main tunnel channel portal to the west of Sæluhúsavatn (Fig. 4a).

Mean flow velocities for each channel cross-section were calculated using three variants of the standard Manning resistance equation as well as an adaptation of the Keulegan equation (Thompson and Campbell, 1979; Russell and others, 1999). The Manning and Keulegan resistance equations required the following input data: (1) the energy gradient or water surface slope; (2) channel hydraulic radius and (3) grain roughness (Chow, 1959; Henderson, 1966; Maizels, 1983). Four methods were used to characterize grain and form roughness in order to identify potential problems of incorporating the channel resistance. Wash limits were located with the help of aerial photographs taken during the jökulhlaup waning stage on 6 November 1996 and surveyed using DGPS. Channel hydraulic radius was calculated from cross-sectional areas and wetted-perimeters derived from surveyed channel cross-sections (Table 1). Channel roughness was characterized by the Darcy-Weisbach friction factor $f$ and Manning's $n$. The modified Keulegan equation proposed by Thompson and Campbell

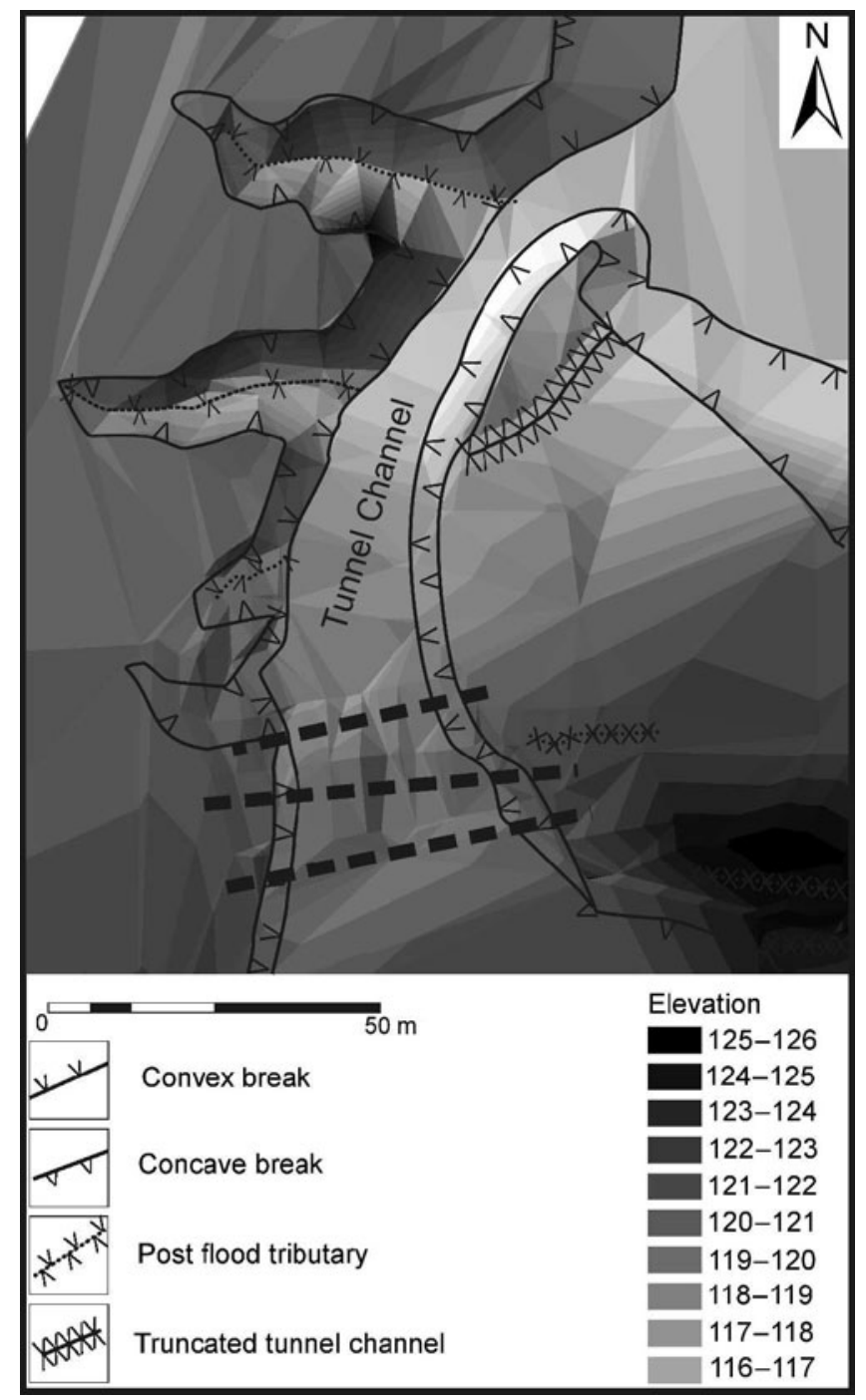

Fig. 6. Geomorphological map of the tunnel channel area indicating the location of the cross-sections used to infer flow conditions.

(1979), being the least empirical and least site-specific, was used to calculate the friction factor $f$ in the Darcy-Weisbach equation (Church and others, 1990). The Darcy-Weisbach equation was used to obtain mean velocity values:

$$
v=\sqrt{\frac{8 g d s}{f}}
$$

where $s$ is the slope, $d$ is the flow depth $(\mathrm{m}), \mathrm{g}$ is the acceleration due to gravity $\left(9.81 \mathrm{~m} \mathrm{~s}^{-2}\right)$ and $f$ is the friction factor calculated using Thompson and Campbell's 1979 equation:

$$
\frac{1}{\sqrt{f}}=\left(1-\frac{k_{\mathrm{s}}}{10 R}\right) \times 2 \log _{10}\left(\frac{12 R}{k_{\mathrm{s}}}\right)
$$

where $R$ is the hydraulic radius and $k_{\mathrm{s}}$ is the size of the roughness elements equal to 4.5 times the boulder size $D_{i}$. In this case, we calculated $k_{\mathrm{s}}$ as the proportion of the flow depth $d$ occupied by flow resistance elements $\Delta A$ :

$$
k_{\mathrm{s}}=4.5 d \Delta A
$$

The proportion of the flow depth occupied by flow resistance elements was estimated visually. A single $f$ value was calculated for each cross-section. Calculated $f$ values were 
Table 1. Input data for flow reconstruction

\begin{tabular}{|c|c|c|c|c|c|}
\hline & $\begin{array}{c}\text { Channel } \\
\text { cross-section } 1\end{array}$ & $\begin{array}{c}\text { Channel } \\
\text { cross-section } 2\end{array}$ & $\begin{array}{c}\text { Channel } \\
\text { cross-section } 3\end{array}$ & $\begin{array}{c}\text { Spillway } \\
\text { cross-section } 1\end{array}$ & $\begin{array}{c}\text { Spillway } \\
\text { cross-section } 2\end{array}$ \\
\hline Cross-sectional area $\left(\mathrm{m}^{2}\right)$ & 520 & 334 & 260 & 220 & 170 \\
\hline Hydraulic Radius (m) & 2.42 & 3.60 & 2.59 & 2.88 & 2.99 \\
\hline Slope $\left(\mathrm{mm}^{-1}\right)$ & 0.006 & 0.008 & 0.01 & 0.01 & 0.01 \\
\hline Width (m) & 210 & 85 & 95 & 70 & 50 \\
\hline Grain size $D_{84}(\mathrm{~m})$ & 0.55 & 0.55 & 0.55 & 0.75 & 0.75 \\
\hline Grain size $D_{90}(\mathrm{~m})$ & 0.6 & 0.6 & 0.6 & 0.8 & 0.8 \\
\hline$\%$ reduction in cross-section area due to roughness & 5 & 5 & 5 & 10 & 10 \\
\hline
\end{tabular}

converted to Manning's $n$ using an equation presented by Richards (1982):

$$
n=\sqrt{\frac{f R^{1 / 3}}{8 g}}
$$

Manning's $n$ values were calculated from grain size characteristics using the Manning-Limerinos and Manning-Strickler equations (Equations 5 and 6), which required estimates of the $D_{84}$ and $D_{90}$ percentiles of the grain size distribution (Maizels, 1983; Ryder and Church, 1986; Russell, 1994):

$$
\begin{aligned}
n & =0.038 D_{90}^{1 / 6} \\
\frac{n}{d^{1 / 6}} & =\frac{0.113}{1.16+2.0 \log \left(d / D_{84}\right)}
\end{aligned}
$$

where $d$ is flow depth and $D_{84}$ and $D_{90}$ are the 84th and 90th percentile grain-size values, respectively. $D_{84}$ and $D_{90}$ percentiles were derived for each cross-section from estimates of surface grain sizes. However, $n$ values calculated from grain-size distributions were compared with those derived solely from water surface slope and the hydraulic radius using Jarrett's equation (Jarrett, 1984):

$$
n=0.32 S^{0.38} R^{-0.16}
$$

where $R$ is the hydraulic radius $(\mathrm{m})$ and $S$ is the energy slope. Mean flow velocities were derived for each proglacial channel cross-section using each of the four variants of the slope-area technique presented above. Peak flood discharges were derived by multiplying mean flow velocities by channel cross-sectional areas.

Average peak jökulhlaup discharge for the Sæluhúsakvísl proglacial channel was reconstructed as $1560 \pm 310 \mathrm{~m}^{3} \mathrm{~s}^{-1}$
(Table 2). Average peak discharge from the main spillway channel exiting the Sæluhúsavatn was reconstructed as $870 \pm 170 \mathrm{~m}^{3} \mathrm{~s}^{-1}$ (Table 2). There is good correspondence of discharge values derived from the various techniques (Table 2). Sensitivity of peak discharge estimates to changes in water surface slope, channel cross-sectional area and grain roughness are presented in Table 3. Slope-area discharge estimates are sensitive to channel cross-sectional area as discharge is the product of resistance-based velocities and cross-sectional areas (Table 3). Although variation of water surface slope and grain roughness has a significant impact on discharge, these parameters can be constrained reliably. The estimated error for each discharge measurement using the slope-area technique is estimated to be $\pm 20 \%$. The difference in average reconstructed discharge between the proglacial and spillway channels $\left(690 \mathrm{~m}^{3} \mathrm{~s}^{-1}\right)$ exceeds the likely errors at each site.

If peak discharge within the proglacial and spillway channels was synchronous, then peak flow exiting the tunnel channel would be $680 \mathrm{~m}^{3} \mathrm{~s}^{-1}$ (Table 2). Dominance of proglacial bars and channels emanating from the tunnel channel portal, however, suggest that flows from the tunnel channel peaked later than those exiting the Sæluhúsavatn basin (Figs 3a and 4a). The peak discharge of $680 \mathrm{~m}^{3} \mathrm{~s}^{-1}$ for the tunnel channel should therefore be regarded as a minimum figure.

Average peak flow velocities within the tunnel channel of $8-14 \mathrm{~m} \mathrm{~s}^{-1}$ are derived by dividing peak discharge, calculated from the proglacial hydraulic reconstructions, by the surveyed channel cross-sectional area. This assumes that the

\begin{tabular}{|c|c|c|c|c|c|}
\hline & $\begin{array}{c}\text { Channel } \\
\text { cross-section } 1 \\
\mathrm{~m}^{3} \mathrm{~s}^{-1}\end{array}$ & $\begin{array}{c}\text { Channel } \\
\text { cross-section } 2 \\
\mathrm{~m}^{3} \mathrm{~s}^{-1}\end{array}$ & $\begin{array}{c}\text { Channel } \\
\text { cross-section } 3 \\
\mathrm{~m}^{3} \mathrm{~s}^{-1}\end{array}$ & $\begin{array}{c}\text { Spillway } \\
\text { cross-section } 1 \\
\mathrm{~m}^{3} \mathrm{~s}^{-1}\end{array}$ & $\begin{array}{c}\text { Spillway } \\
\text { cross-section } 2 \\
\mathrm{~m}^{3} \mathrm{~s}^{-1}\end{array}$ \\
\hline Darcy-Weisbach & $1880 \pm 380$ & $1730 \pm 350$ & $1270 \pm 250$ & $910 \pm 180$ & $720 \pm 140$ \\
\hline Manning-Limerinos & $1370 \pm 270$ & $1420 \pm 280$ & $940 \pm 190$ & $800 \pm 160$ & $650 \pm 130$ \\
\hline Manning-Strickler & $2090 \pm 420$ & $2020 \pm 400$ & $1410 \pm 280$ & $1220 \pm 240$ & $970 \pm 190$ \\
\hline Average & $1790 \pm 360$ & $1720 \pm 340$ & $1160 \pm 230$ & $970 \pm 190$ & $770 \pm 150$ \\
\hline Proglacial average & $1560 \pm 310$ & & & & \\
\hline Spillway average & $870 \pm 170$ & & & & \\
\hline Tunnel channel component & $680 \pm 140$ & & & & \\
\hline
\end{tabular}
tunnel channel was subject to bank-full conditions and that there was no tunnel roof expansion. Observations of the

Table 2. Discharge estimates 
Table 3. Sensitivity of discharge reconstruction techniques to changes in input parameters

+0.01 slope

$+10 \mathrm{~m}^{2}$ cross-sectional area

$+10 \mathrm{~cm}$ grain roughness

\begin{tabular}{llll}
\hline$\%$ discharge increase in main channel & +5.3 & +4.7 & -2.5 \\
$\%$ discharge increase in spillway channel & +4.0 & +8.6 & -4.8
\end{tabular}

outlet in April 1997 indicate that the conduit was mainly sediment-walled, showing little upward expansion into the glacier (Fig. 5a).

\section{DISCUSSION}

The case for a tunnel channel feeding the Sæluhúsakvísl proglacial outwash fan is supported by: (1) the clear association of the freshly cut channel ascending from the lower Sæluhúsavatn basin and the proglacial outwash fan (Figs 3, 4 and 6); (2) the lack of any major meltwater outlet or proglacial outwash fan in the Sæluhúsakvísl area prior to the jökulhlaup as indicated by oblique aerial photos taken in August 1996; (3) repeated ground and aerial observations since 1996 that do not indicate any major meltwater flow from the 1996 ice margin towards the upper Sæluhúsavatn basin capable of generating the channel system (Figs 3a and $4 \mathrm{a}$ ) and (4) observations of the outlet channel cutting through adjacent moraine deposits in April 1997 (Figs 5a and $b$ ). The presence of numerous rip-up clasts on the proglacial fan surface confirms that major subglacial excavation took place at this location during the 1996 jökulhlaup (Figs $5 b$ and c). Estimated volumes of sediment eroded from the tunnel channel account for 20 to $34 \%$ of the volume of the proglacial outwash fan, highlighting the importance of subglacial tunnel channel erosion as a source of sediment to the jökulhlaup at this site. Many of the outwash fans draining the eastern side of Skeiðarárjökull are heavily incised by waning stage flows implying rapid and marked reductions in sediment supply (Russell and Knudsen, 2002; Russell and others, 2006).

Although there is evidence of subaqueous jökulhlaup efflux into the upper Sæluhúsavatn basin at an elevation of $110 \mathrm{~m}$, a substantial discharge ascended the flanks of the lower basin through the tunnel channel to exit at an elevation of $120 \mathrm{~m}$ (Fig. 3). Aided by subaerial and the aforementioned subaqueous jökulhlaup influx, the level of the Sæluhúsavatn rose from $117 \mathrm{~m}$ to $125 \mathrm{~m}$ allowing the formation of a delta graded to a lake level of $125 \mathrm{~m}$ (Fig. 2a). The temporarily raised proglacial lake levels acted as a hydraulic dam deflecting subglacial jökulhlaup flow up the western flank of the upper basin to exit the glacier margin at an elevation of $120 \mathrm{~m}$ (Figs 3, 4 and 6). Within-flood changes in hydraulic conditions can therefore be seen to have a significant impact on meltwater flow routing and tunnel channel trajectory. In addition, the presence of a smaller truncated tunnel channel ascending from the upper Sæluhúsavatn basin suggests progressive channel evolution, possibly from an anastomosing to a single channel (cf. Brennand and others, 2006).

The Sæluhúsakvísl tunnel channel and proglacial outwash fan described in this paper show many similarities to those described from Quaternary ice marginal zones (e.g. Clayton and others, 1999; Cutler and others, 2002;
Kozlowski and others, 2005; Jørgensen and Sandersen, 2006). Similarities between the Sæluhúsakvísl and Quaternary tunnel channel systems include: up-glacier slopes; associated outwash fans displaying rapid downstream fining and apex incision; dissection of end moraines and a characteristic 'box' shape (Clayton and others, 1999; Cutler and others, 2002; Kozlowski and others, 2005). Clayton and others (1999) and Cutler and others (2002) attributed channels cut into outwash fan apexes in Wisconsin to erosion during the waning stage of a tunnel-channel flood. Absence of ice-block obstacle marks or kettle-holes on proglacial outwash fans led Cutler and others (2002) to conclude that tunnel discharge had been relatively modest or that they had been covered by deposits of later lower magnitude flows. Interestingly, 1996 jökulhlaup flows within the Sæluhúsakvísl channel were noted to have a modest number of ice blocks when compared to adjacent outlets. Flood flow within sediment-walled tunnel channels will not result in as much ice removal as en- or supraglacial conduits which are subject to vigorous erosion processes during jökulhlaups (Roberts and others, 2001; Roberts, 2005).

Our modern analogue has demonstrated a close relationship between tunnel channel erosion and proglacial outwash deposition. The data presented clearly demonstrate the ability of meltwater, under these conditions, to erode under appropriate local hydraulic gradients and in the presence of erodible glacier substrate. Tunnel channel formation in Iceland takes place beneath temperate glacier ice in the absence of permafrost. The November 1996 jökulhlaup had a sufficiently rapid onset to induce water pressures high enough to force large volumes of water to ascend from a heavily over-deepened glacier basin. Many Quaternary tunnel channels ascend to ice margins from over-deepened basins (Clayton and others, 1999; Cutler and others, 2002; Jørgensen and Sandersen, 2006). Over-deepened basins may encourage tunnel channel formation as ascending subglacial meltwater will seek the most efficient route through highly erodible and complex glacier substrate. The presence of an over-deepened basin may also help retain meltwater within subglacial lakes (e.g. Shoemaker, 1992; Alley and others, 2006; Domack and others, 2006) thereby providing a source of water for release during tunnel channel forming bursts.

\section{CONCLUSIONS AND WIDER IMPLICATIONS}

For the first time at a contemporary glacial margin, we have demonstrated that glacier outburst floods are capable of generating tunnel channels. In our Icelandic example, tunnel channel routing is controlled by subglacial topography and rapid changes in subglacial and proglacial hydraulic gradients during the 1996 jökulhlaup. One cannot explain the location or trajectory of the tunnel channel discussed in this paper without recourse to transient icemarginal hydraulic conditions during the 1996 jökulhlaup. 
This paper demonstrates the need for greater attention to be paid to the interaction of proglacial lakes as a control on subglacial meltwater flow routing (see also Brennand, 2000). We suggest that the presence of proglacial lakes will increase the variability of geomorphologic response and sedimentary signature of glacier outburst floods over distances as little as a few hundred metres. Our study highlights the importance of meltwater outbursts as agents of tunnel channel formation and provides a valuable modern analogue for a process which has until now only been inferred from the Quaternary record. Further research is required to determine the origin of the lower Sæluhúsavatn basin which, being of composite origin, can be classified as a tunnel valley.

\section{ACKNOWLEDGEMENTS}

We acknowledge fieldwork grants from Earthwatch and the UK Natural Environment Research Council (GR3/10960, AJR). We thank Ragnar Frank Kristjánsson for supporting our research within Skaftafell National Park and the July 2005 and April 2006 Earthwatch volunteers for field assistance. This manuscript was greatly improved by reviews from L. Clayton and T. Brennand as well as editorial comments by Gudfinna Aðalgeirsdóttir.

\section{REFERENCES}

Allen, J.R.L. 1982a. Sedimentary structures: their character and physical basis, volume 1. Developments in Sedimentology. 30A. Amsterdam, Elsevier.

Allen, J.R.L. 1982b. Sedimentary structures: their character and physical basis, volume 2. Developments in Sedimentology. $30 \mathrm{~B}$. Amsterdam, Elsevier.

Alley, R.B. and 6 others. 2006. Outburst flooding and surge initiation in response to climatic cooling: a hypothesis. Geomorphology, 75(1-2), 76-89.

Ashley, G.M., J.B. Southard and J.C. Boothroyd. 1982. Deposition of climbing-ripple beds: a flume simulation. Sedimentology, 29(1), 67-79.

Beaney, C.L. 2002. Tunnel channels in southeast Alberta, Canada: evidence for catastrophic channelized drainage. Quat. Int., 90, $67-74$.

Björnsson, H. 1996. Scales and rates of glacial sediment removal: a $20 \mathrm{~km}$ long, $300 \mathrm{~m}$ deep trench created beneath Breiðamerkurjökull during the Little Ice Age. Ann. Glaciol., 22, 141-146.

Björnsson, H. 1998. Hydrological characteristics of the drainage system beneath a surging glacier. Nature, 395(6704), 771-774.

Björnsson, H. 2002. Subglacial lakes and jökulhlaups in Iceland. Global Planet. Change, 35(3-4), 255-271.

Boulton, G.S. and R.C.A. Hindmarsh. 1987. Sediment deformation beneath glaciers: rheology and geological consequences. J. Geophys. Res., 92(B9), 9059-9082.

Brennand, T.A. 2000. Deglacial meltwater drainage and glaciodynamics: inferences from Laurentide eskers, Canada. Geomorphology, 32(3), 263-293.

Brennand, T.A. and J. Shaw. 1994. Tunnel channels and associated landforms, south-central Ontario: their implications for ice-sheet hydrology. Can. J. Earth Sci., 31(3), 505-522.

Brennand, T.A., H.A.R. Russell and D.R. Sharpe. 2006. Tunnel channel character and evolution in central southern Ontario. In Knight, P., ed. Glacier science and environmental change. Oxford: Blackwell Publishing. 37-38.

Chow, V.T. 1959. Open-channel hydraulics. New York, McGrawHill.

Church, M., J. Wolcott and J. Maizels. 1990. Palaeovelocity: a parsimonious proposal. Earth Surf. Proc. Land., 15(5), 475-480.
Clayton, L., J.W. Attig and D.M. Mickelson. 1999. Tunnel channels formed in Wisconsin during the last glaciation. In Mickelson, D.M. and J.W. Attig, eds. Glacial processes: past and present. Boulder, CO, Geological Society of America, 69-82. (Special Paper 337.)

Culter, P.M., P.M. Colgan and D.M. Mickelson. 2002. Sedimentologic evidence for outburst floods from the Laurentide Ice Sheet margin in Wisconsin, USA: implications for tunnel-channel formation. Quat. Int., 90, 23-40.

Domack, E. and 7 others. 2006. Subglacial morphology and glacial evolution of the Palmer deep outlet system, Antarctic Peninsula. Geomorphology, 75(1-2), 125-142.

Ehlers, J. and G. Linke. 1989. The origin of deep buried channels of Elsterian age in NW Germany. J. Quaternary Sci., 4(3), 255-265.

Eyles, N. and P. de Broekert. 2001. Glacial tunnel valleys in the Eastern Goldfields of Western Australia cut below the Late Paleozoic Pilbara ice sheet. Paleography, Paleoclimatology, Paleoecology, 171, 29-40.

Fay, H. 2002. The formation of ice-block obstacle marks during the November 1996 glacier outburst (jökulhlaup) Skeiðarársandur, southern Iceland. In Martini, I.P., V.R. Baker and G. Garzon, eds. Flood and megaflood procecesses and deposits: recent and ancient. International Association of Sedimentologists, 85-97. (Special Publication 32.)

Fisher, T.G., H.M. Jol and A.M. Boudreau. 2005. Saginaw Lobe tunnel channels (Laurentide Ice Sheet) and their significance in south-central Michigan, USA. Quat. Sci. Rev., 24(22), 2375-2391.

Flowers, G.E., H. Björnsson, R. Pálsson and G.K.C. Clarke. 2004. A coupled sheet-conduit mechanism for jökulhlaup propogation. Geophys. Res. Lett., 31(L05401). (10.1029/2003GL019088.)

Ghienne, J.F. and M. Deynoux. 1998. Large-scale channel fill structures in late Ordovician glacial deposits in Mauritania, western Sahara. Sediment. Geol., 119, 141-159.

Guðmundsson, M.T., F. Sigmundsson and H. Björnsson. 1997. Icevolcano interaction of the 1996 Gjálp subglacial eruption, Vatnajökull, Iceland. Nature, 389(6654), 954-957.

Henderson, F.M. 1966. Open channelflow. New York, Macmillan Co.

Hooke, R.L. and C.E. Jennings. 2006. On the formation of the tunnel valleys of the southern Laurentide ice sheet. Quat. Sci. Rev., 25, 1364-1372.

Huuse, M. and H. Lykke-Andersen. 2000. Overdeepened quaternary valleys in the eastern Danish North Sea: morphology and origin. Quat. Sci. Rev., 19, 1233-1253.

Jarrett, R.D. 1984. Hydraulics of high gradient streams. Journal of Hydraulic Engineering, 110(11), 1519-1539.

Jóhannesson, T. 2002. Propagation of a subglacial flood wave during the initiation of a jökulhlaup. Hydrological Sciences Journal, 47(3), 417-434.

Johnson, M.D. 1999. Spooner Hills, northwest Wisconsin: highrelief hills carved by subgiacial meltwater of the Superior Lobe. In Mickelson, D.M. and J.W. Attig, eds. Glacial processes: past and present. Boulder, CO, Geological Society of America, 8392. (Special Paper 337.)

Jørgensen, F. and P.B.E. Sandersen. 2006. Buried and open tunnel valleys in Denmark - erosion beneath multiple ice sheets. Quat. Sci. Rev., 25(11-12), 1339-1363.

Kozlowski, A.L., A.E. Kehew and B.C. Bird. 2005. Outburst flood origin of the Central Kalamazoo River Valley, Michigan, USA. Quarterly Science Reviews, 24(22), 2354-2374.

Maizels, J.K. 1983. Palaeovelocity and palaeodischarge determination for coarse gravel deposits. In Gregory, K.J., ed. Background to paleohydrology. John Wiley and Sons, 101-139.

Mooers, H. 1989. On the formation of tunnel valleys of the Superior lobe, central Minnesota. Quat. Res., 32(1), 24-35.

O'Cofaigh, C. 1996. Tunnel valley genesis. Prog. Phys. Geog., 20(1), 1-19.

Piotrowski, J.A. 1997. Subglacial hydrology in north-western Germany during the last glaciation: groundwater flow, tunnel valleys and hydrological cycles. Quat. Sci. Rev., 16(2), 169-185. 
Praeg, D. 2003. Seismic imaging of mid-Pleistocene tunnel-valleys in the north Sea Basin-high resolution from low frequencies. J. Appl. Geophys., 53(4), 273-298.

Richards, K.S. 1982. Rivers: form and process in alluvial channels. New York, Methuen \& Co.

Roberts, M.J. 2005. Jökulhlaups: a reassessment of floodwater flow through glaciers. Rev. Geophys., 43(RG1002). (10.1029/ 2003RG000147.)

Roberts, M.J., A.J. Russell, F.S. Tweed and Ó. Knudsen. 2000. Ice fracturing during jökulhlaups: implications for englacial floodwater routing and outlet development. Earth Surf. Processes Landforms, 25(13), 1429-1446.

Roberts, M.J., A.J. Russell, F.S. Tweed and Ó. Knudsen. 2001. Controls on englacial sediment deposition during the November 1996 jökulhlaup, Skeiðarárjökull, Iceland. Earth Surf. Proc. Land., 26(9), 935-952.

Roberts, M.J. and 7 others. 2002. Glaciohydraulic supercooling in Iceland. Geology, 30(5), 439-442.

Russell, A.J. 1994. Subglacial jökulhlaup deposition, Jotunheimen, Norway. Sediment. Geol., 91(1-4), 131-144. In Dardis, G.F. and A.M. McCabe, eds. Subglacial Processes, Sediments and Landforms. Proceedings of Symposium on Subglacial Processes and Landforms, July 1992, University of Ulster.

Russell, A.J. and Ó. Knudsen. 1999. Controls on sedimentology of November 1996 jökulhlaup deposits, Skeiðarárjökull, Iceland. In Smith, N. D. and J. Rogers, eds. Fluvial Sedimentology VI. International Association of Sedimentologists, 315-329. (Special Publication 28.)

Russell, A.J. and Ó. Knudsen. 2002. The effects of glacieroutburst flood flow dynamics in ice-contact deposits: November 1996 jökulhlaup, Skeiðarárjökull, Iceland. In Martini, I.P., V.R. Baker and G. Garz'n, eds. Flood and megaflood processes and deposits: recent and ancient examples. International Association of Sedimentologists, 67-83. (Special Publication 32.)

Russell, A.J., Ó. Knudsen, J.K. Maizels and P.M. Marren. 1999. Channel cross-sectional area changes and peak discharge calculations on the Gígjukvísl during the November 1996 jökulhlaup, Skeiðarárjökull, Iceland. Jökull, 47, 45-58.

Russell, A.J. and 6 others. 2006. Icelandic jökulhlaup impacts: implications for ice-sheet hydrology, sediment transfer and geomorphology. Geomorphology, 75(1-2), 33-64.
Russell, H.A.J., R.W.C. Arnott and D.R. Sharpe. 2003. Evidence for rapid sedimentation in tunnel channel, Oak Ridges Moraine, Southern Ontario, Canada. Sediment. Geol., 160(1), 33-55.

Ryder, J.M. and M. Church. 1986. The Lillooet terraces of Fraser River: a palaeoenvironmental enquiry. Can. J. Earth Sci., 23(6), 869-884.

Shoemaker, E.M. 1992. Water sheet outburst floods from the Laurentide ice sheet. Can. J. Earth Sci., 29(6), 1250-1264.

Sjogren, D.B., T.G. Fisher, L.D. Taylor, H.M. Jol and M.J. MunroStasiuk. 2002. Incipient tunnel channels. Quat. Int., 90, 41-56.

Smith, L.N. 2004. Late pleistocene stratigraphy and implications for deglaciation and subglacial processes of the Flathead Lobe of the Cordilleran Ice Sheet, Flathead Valley, Montana USA. Sediment. Geol., 165, 295-332.

Snorrason, Á. And 7 others. 1997. Hlaupið á Skeiðarársandi haustið 1996: útbreidsla, rennsli og aurburdur. In Haraldsson, H., ed. Vatnajökull: gos og hlaup 1996. Reykjavík, Vegagerdin, 79-137.

Snorrason, Á., P. Jónsson, S. Pálsson, S. Árnason, S. Víkingsson and I. Kaldal. 2002. November 1996 jökulhlaup on Skeiðarársandur outwash plain, Iceland. In Martini, I.P., V.R. Baker and G. Garz'n, eds. Flood and megaflood processes and deposits: recent and ancient examples. International Association of Sedimentologists, 55-65. (Special Publication 32.)

Stefánsdóttir, M.B., S.R. Gíslason and S. Arnórsson. 1999. Flood from Grímsvötn subglacial caldera 1996: composition of suspended matter. In Armannsson, H., ed. Geochemistry of the Earth's Surface. Balkema, 539-542.

Thompson, S.M. and P.L. Campbell. 1979. Hydraulics of a large channel paved with boulders. Journal of Hydraulic Research, 17, 341-354.

Waller, R.I., A.J. Russell, T.A.G.P. van Dijk and Ó. Knudsen. 2001. Jökulhlaup-related ice fracture and supraglacial water release during the November 1996 jökulhlaup, Skeiðarárjökull, Iceland. Geogr. Ann., 83A(1-2), 29-38.

Wingfield, R. 1989. Glacial incisions indicating middle and upper Pleistocene ice limits off Britain. Terra Nova, 1, 538-548.

Wingfield, R. 1990. The origin of major incursions within the Pleistocene deposits of the North Sea. Mar. Geol., 91(1-2), 31-52.

Wright, H.E., Jr. 1973. Tunnel valleys, glacial surges, and subglacial hydrology of the Superior lobe, Minnesota. Geological Society of America Memoir, 136, 251-276. 